\title{
ESTIMATION OF GHG EMISSIONS FROM POINT OF VIEW OF LITTER MANURE MANAGEMENT IN LITHUANIAN AGRICULTURE
}

\author{
Ramunas Mieldazys $^{1}$, Egle Jotautiene ${ }^{1}$, Algirdas Jasinskas ${ }^{1}$, Aivars Aboltins ${ }^{2}$ \\ ${ }^{1}$ Vytautas Magnus University, Lithuania; ${ }^{2}$ Latvia University of Life Sciences and Technologies, Latvia \\ ramunas.mieldazys@vdu.lt, egle.jotautiene@vdu.lt, algirdas.jasinskas@vdu.lt, aivars.aboltins@1lu.lv
}

\begin{abstract}
The article analyses the emissions of carbon dioxide (CO2), methane (CH4) and dinitrogen monoxide (N2O) in the litter manure management and composting technologies. The impact of agricultural activity on climate change has been observed in the recent years. This was found to be related to structural changes in the holding of farm animals. From 2011 to 2018, the number of farms holding up to 50 cattle decreased by $41 \%$, but by $17 \%$ increased the number of farms holding 50 and more cattle in Lithuania agriculture. Calculations have shown that greenhouse gas emission in dense manure management systems is about $862.06 \mathrm{kt} \mathrm{CO} 2 \mathrm{e}$, and that emissions of soils and pastures make up about $2282 \mathrm{ktCO} 2 \mathrm{e}$ in Lithuania. According to the EU legal requirements, manure is considered to be waste the livestock owner has to account for and eliminate using as crop fertilizer and not polluting the environment. One of this biodegradable waste management ways is granulation, as processing of recyclable materials into organic products. Manure compost granulation can increase bulk density, improve storability, reduce transportation costs, and make these materials easier to handle using existing handling and storage equipment, also there can be GHG emission reduction effect achieved in manure compost granulation technology. Experimental studies have shown that the maximum $\mathrm{CO} 2$ emissions of ground cattle manure compost and its granules are 9 times lower, and emissions from a surface area up to 28 times lower than $\mathrm{CO} 2$ emissions from fresh cattle manure.
\end{abstract}

Keywords: GHG emissions, methane, dinitrogen monoxide, carbon dioxide, compost, granules.

\section{Introduction}

The main greenhouse gases (GHGs) in manure management systems are methane $\left(\mathrm{CH}_{4}\right)$, dinitrogen monoxide $\left(\mathrm{N}_{2} \mathrm{O}\right)$ and carbon dioxide $\left(\mathrm{CO}_{2}\right)$. Agriculture is the second most significant source and accounted for $21.5 \%$ of the total emissions $[1 ; 2]$.

The agricultural sector is the second contributor to the worldwide emissions of greenhouse gases (GHG), as it is responsible for $13.5 \%$ of GHG emissions. Obtained results by scientists showed that between 1990 and 2016 most of the EU-27 countries witnessed a significant reduction of GHG emissions from the agricultural sector [3]. Livestock farming has an impact on global warming with about $10 \%$ of total GHG emissions from the EU-27. The dairy sector had the highest GHG emission in the EU-27, with annual emission of $195 \mathrm{Tg} \mathrm{CO}_{2}$-eq. Enteric fermentation was the main source of GHG emissions in the European livestock sector (36\%) followed by $\mathrm{N}_{2} \mathrm{O}$ soil emissions ( $28 \%$ ) based on 2003-2005 data [4].

From 1990 to 2010, GHG emissions in the Lithuanian agriculture decreased 2.3 times, while in 2010 they stabilised and made $21.4 \%$. However, in 2016, GHG emissions increased to $22.9 \%$. Increase of emissions is related to increase in the number of livestock in certain categories and the increasing demand for quality food [2]. The country's growing economy is inevitably linked to higher $\mathrm{CO}_{2}$ emissions. In the period 2021-2030, the EU predicts a reduction of GHG emissions up to $40 \%$. Lithuania has committed to reduce GHG emissions in agriculture by about 10-12\%.

One of the most important challenges for livestock farming is the use of safe and environmentally friendly production methods. Particular attention must be paid to clean and environmentally friendly technologies that allow more efficient use of resources, reduction of potential pollution, mitigation and adaptation to climate change [5]. The most important sources of concentrated pollution are livestock farms. As livestock farms grow, large quantities of livestock and manure are concentrated in agricultural areas.

The aim of the work is to estimate GHG emissions according to statistical changes in livestock numbers and manure production, and advanced litter manure management technologies.

\section{Materials and methods}

In 2016, the Lithuanian Energy Institute prepared Methodological guidelines for GHG forecast [1]. Tier1 and Tier2 methodologies should be used to calculate GHG emissions [6]. According to the Tier1 method, it is sufficient to know the number of livestock by category and emission factor. For 
example, methane $\mathrm{CH}_{4}$ emissions $\left(\mathrm{Gg} \mathrm{CH}_{4} \mathrm{yr}^{-1}\right)$ from manure management, for a defined population can be calculated using this simplified equation.

$$
\mathrm{CH}_{4}{ }^{\text {emision }}=\sum_{(T)}\left(E F_{(T)} \text { populiation }(T)^{(T)}\right),
$$

where $E F_{(T)}-$ emission factor for the defined livestock population, $\mathrm{kg} \mathrm{CH}_{4}$ animal $^{-1} \mathrm{yr}^{-1}$

$T$ - number of head in the population of livestock category, units.

The Tier2 method is more detailed, evaluating manure management systems, manure composition, gas conversion rates and other factors. Simplified methods for calculating gas emissions can be used to determine general manure emissions, their changes and trends [1]. Emission of direct $\mathrm{N}_{2} \mathrm{O}$ emissions can be calculated using this simplified equation [6].

$$
\mathrm{N}_{2} \mathrm{O}^{\text {emmision }}=\sum_{(T)}\left(N_{(T)} \cdot N e x_{(T)} \cdot M S_{(T, S)}\right) \cdot E F_{3(S)},
$$

where $N_{(T)}$ - number of head in the population of livestock category, units;

$\mathrm{Nex}_{(T)}$ - annual average $\mathrm{N}$ excretion per head for livestock category, $\mathrm{kg} \mathrm{N}$ animal ${ }^{-1} \cdot \mathrm{yr}^{-1}$;

$M S_{(T, S)}$ - fraction of total annual $\mathrm{N}$ excretion for each livestock category $T$;

$E F_{3(S)}$ - emission factor for direct $\mathrm{N}_{2} \mathrm{O}$ emissions, $\mathrm{kg} \mathrm{N}_{2} \mathrm{O}-\mathrm{N} \cdot(\mathrm{kg} \mathrm{N})^{-1}$;

$S$ - manure management system;

$T$ - livestock category, units.

Enterprise "Agrolinija", which owns 378 beef cattle and 186 suckler cows, was chosen as the object for the experimental research. During the barn period, all animals are housed in three barns on deep litter (straw). About 6 thousand $\mathrm{m}^{3}$ of littered manure are accumulated per year. During the barn period, in two stables part of the manure is put to compost heaps, and the rest is dumped into the manure storage. The enterprise declares about 1000 ha of cultivated soil, according to the number of livestock, manure is used for fertilization of about 200 ha of soil. The amount of livestock manure applied to the soil each year, including livestock manure, may not exceed $170 \mathrm{~kg}$ nitrogen per hectare and $25 \mathrm{~kg}$ phosphorus per hectare and other requirements [7]. The technological scheme of litter manure composting, granulating and spreading in soil is presented in Fig. 1.

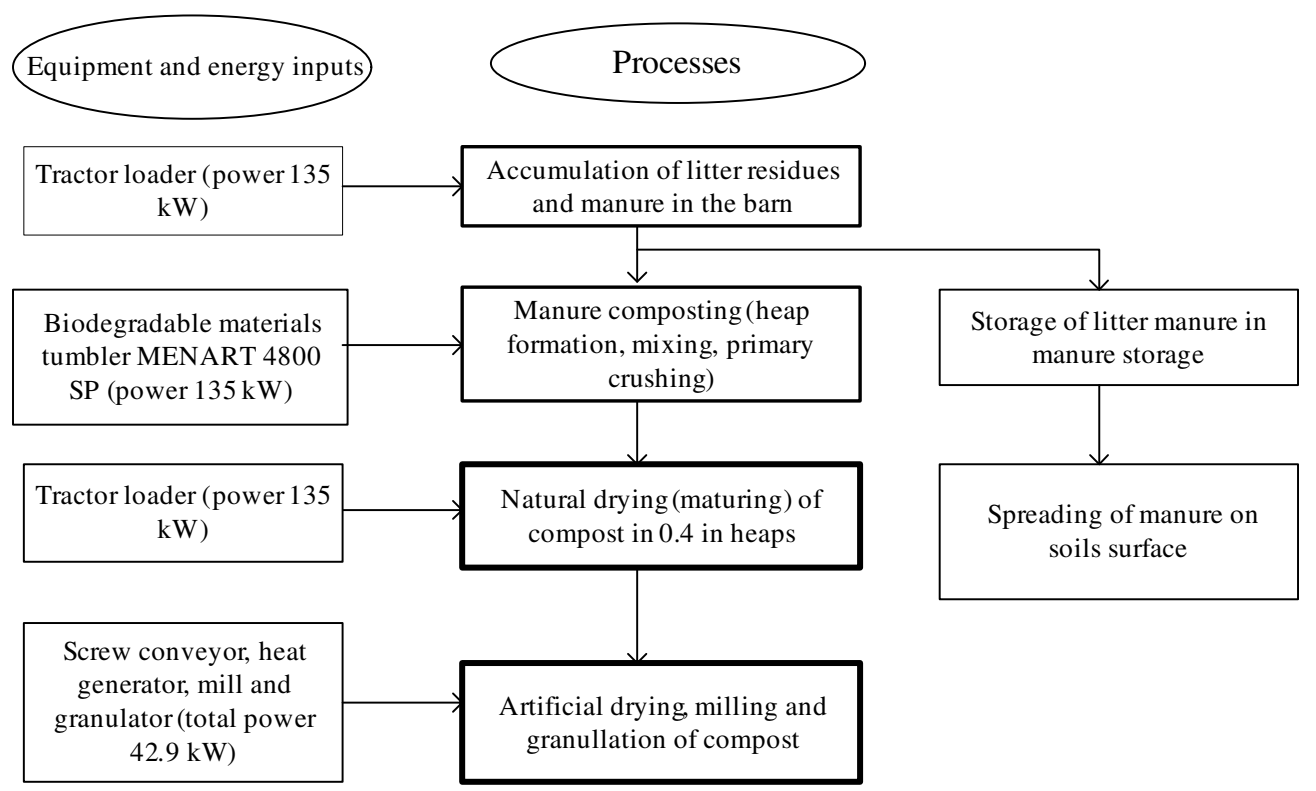

Fig. 1. Technologies for composting, granulation and surface spreading of cattle manure

Compost production begins with taking out the cattle from the farm for the summer season to pasture. Stacks of composted manure are mixed several times. It is very important to choose the right amount of manure mixes, as this determines the quality of the raw material used for production of milled compost and granular fertilizers. During the next stage, the compost is transported to natural drying (maturing) premises. The compost maturation process takes place until the moisture content of 
the compost does not exceed $30 \%$. At the beginning, milled cattle manure compost is produced, and later it is used for production of granulated manure compost fertilizers.

In laboratory conditions a thermal camera of $1.05 \mathrm{~m}^{3}$ capacity was used to estimate emissions of fresh manure of livestock cattle, composting, maturation and granulation products, which maintained a constant temperature with the help of the thermostat. Concentration of carbon dioxide $\left(\mathrm{CO}_{2}\right)$ was measured with a portable $\mathrm{CO}_{2}$, temperature, and humidity meter $\mathrm{AZ} 77535$ with a $\mathrm{CO}_{2}$ measurement range of 0 to $9999 \mathrm{ppm}$, with an error of $\pm 30 \mathrm{ppm}$; temperature measurement range -10 to $+60{ }^{\circ} \mathrm{C}$, tolerance $\pm 0.6^{\circ} \mathrm{C}$. Based on the measured maximum $\mathrm{CO}_{2}$ concentrations, $\mathrm{CO}_{2}$ emissions were calculated using modified equation 3 in the relevant manure management technological operations [8]:

$$
F=V M p\left(C_{1}-C_{0}\right) R^{-1}(T+273)^{-1} A^{-1} h,
$$

where $F-\mathrm{CO}_{2}$ emission rate, $\mathrm{mg} \cdot \mathrm{m}^{-2} \cdot \mathrm{h}^{-1}$;

$V$ - camera volume $\left(1.05 \mathrm{~m}^{3}\right)$;

$M$ - mole mass of gas $\left(44.01 \mathrm{~g} \cdot \mathrm{mol}^{-1}\right)$;

$p$ - gas pressure $(101.08 \mathrm{kPa})$;

$C_{1}$ - maximum gas concentration in the chamber, ppm;

$C_{0}$ - gas concentration in the chamber at the beginning of measurement, ppm;

$R$ - gas constant $\left(8.314 \mathrm{~J} \mathrm{~K}^{-1} \cdot \mathrm{mol}^{-1}\right)$;

$T$ - gas temperature $\left(20^{\circ} \mathrm{C}\right)$;

$A$ - surface area of manure $\left(0.5 \mathrm{~m}^{2}\right.$, amount of manure 31$)$;

$h$ - gas measurement period $(0.08 \mathrm{~h})$.

A methodology for evaluation of $\mathrm{CH}_{4}$ and other $\mathrm{GHG}$ emissions from manure management systems shall be applied [6].

\section{Results and discussion}

According to the EU requirements, manure is considered as waste that the owner of the livestock must account for and dispose of without polluting the environment. Thus, the legal responsibility for the proper management of manure rests with all producers, and it is logical to assume that large and medium-sized farms can do this more rationally and that small producers should withdraw from the market. In Lithuania, this process is already very intensive, as between 2011 and 2016 the number of small livestock farms decreased by $41 \%$ and the number of medium and large farms with 50 and more cattle increased by $17 \%$. However, a bigger problem is that the quantities of manure that continue to be produced are almost unrecorded on small and some medium-sized farms. The main factors affecting GHG emissions are changes in livestock numbers and technological solutions in manure management systems. According to 2018 Lithuanian statistics publication, the number of dairy cows decreased, but the number of other livestock and the amount of litter manure increased [9]. For calculations there were used 2017 statistic data [9]. Table 1 shows the number of livestock by category and the amount of manure entering the manure management systems.

Table 1

Number of livestock by category and amount of manure produced (2017)

\begin{tabular}{|c|c|c|c|}
\hline Livestock category & $\begin{array}{c}\text { Number of } \\
\text { animals, } \\
\text { thousand }\end{array}$ & $\begin{array}{c}\text { Quantity of litter } \\
\text { manure, thousand, } \mathbf{t}\end{array}$ & $\begin{array}{c}\text { Quantities of manure } \\
\text { spread in soil, } \\
\text { thousand, } \mathbf{~}\end{array}$ \\
\hline Cattle & 404.1 & 286.6 & 252.1 \\
\hline Dairy cows & 272.8 & 391.3 & 290.2 \\
\hline Pigs & 611.9 & 230.3 & 150.7 \\
\hline Others (sheep, goats, etc.) & 169.7 & 56.8 & 54.9 \\
\hline Poultry (98\% hens) & 10400 & 333.4 & 290.8 \\
\hline Total & & 1298.4 & 1038.7 \\
\hline
\end{tabular}

The results of calculation of methane $\left(\mathrm{CH}_{4}\right)$ emissions are presented in Table 2. According to the statistically declared livestock numbers and the resulting litter manure quantities in 2017, a potential methane emission makes about $15.32 \mathrm{ktCH}_{4}$. 
Methane $\left(\mathrm{CH}_{4}\right)$ emissions from litter manure systems (2017)

\begin{tabular}{|c|c|c|c|c|}
\hline $\begin{array}{l}\text { Livestock } \\
\text { category }\end{array}$ & $\begin{array}{c}\text { Number of } \\
\text { animals, thousand }\end{array}$ & $\begin{array}{l}\text { Emission factor, } \\
\mathbf{k g C H}_{4} \text { animal }^{-1} \mathbf{y r}^{-1}\end{array}$ & $\begin{array}{c}\text { Emission, } \\
\mathrm{ktCH}_{4}\end{array}$ & $\begin{array}{l}\text { Emission, } \\
\mathrm{CH}_{4} \mathrm{kt} \mathrm{CO}_{2} \mathrm{e}\end{array}$ \\
\hline Cattle & 404.1 & 5.72 & 2.31 & 57.75 \\
\hline Dairy cows & 272.8 & 9.64 & 2.63 & 65.75 \\
\hline Swine & 611.9 & 4.0 & 2.45 & 61.25 \\
\hline Poultry & 10400.0 & 0.73 & 7.59 & 189.75 \\
\hline Others & 169.7 & 1.98 & 0.34 & 8.50 \\
\hline \multicolumn{3}{|r|}{ Total } & 15.32 & 383.00 \\
\hline
\end{tabular}

Having conversed $\mathrm{CO}_{2}$ equivalent value (coefficient 25), we get $383.0 \mathrm{CH}_{4} \mathrm{ktCO}_{2}$ e. Based on the number of livestock, the highest $\mathrm{CH}_{4}$ emission comes from poultry manure $\left(189.75 \mathrm{CH}_{4} \mathrm{kt} \mathrm{CO}_{2} \mathrm{e}\right)$. Emissions from cattle, cows and swine manure differ insignificantly.

Emissions of $\mathrm{N}_{2} \mathrm{O}$ were calculated in two steps. The first step was to calculate nitrogen excretion in $\mathrm{N} \mathrm{kg} \cdot \mathrm{t}^{-1}$ followed by $\mathrm{N}_{2} \mathrm{O}$ emissions by livestock category. The calculation results are shown in Table 3 .

Table 3

Emission of dinitrogen monoxide $\left(\mathrm{N}_{2} \mathrm{O}\right)$ in litter manure systems (2017)

\begin{tabular}{|c|c|c|c|c|}
\hline $\begin{array}{l}\text { Livestock } \\
\text { category }\end{array}$ & $\begin{array}{l}\text { Quantity of } \\
\text { manure, } \\
\text { thousand, } t\end{array}$ & 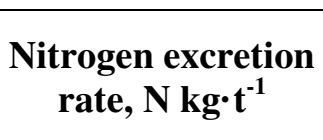 & $\begin{array}{l}\text { Emission, } \\
\mathrm{ktN}_{2} \mathrm{O}\end{array}$ & $\begin{array}{c}\text { Emission, kt } \mathrm{N}_{2} \mathrm{O} \\
\mathrm{CO}_{2} \mathrm{e}\end{array}$ \\
\hline Cattle & 511.8 & 70 & 0.36 & 108 \\
\hline Dairy cows & 869.6 & 100 & 0.87 & 267 \\
\hline Swine & 1151.7 & 20 & 0.23 & 69 \\
\hline Poultry & 333.4 & 0,6 & 0.02 & 6 \\
\hline Others & 56.8 & 16 & 0.09 & 27 \\
\hline \multicolumn{3}{|r|}{ Total: } & 1.5 & 477 \\
\hline
\end{tabular}

According to the declared manure amount, a total emission of $1.5 \mathrm{ktN}_{2} \mathrm{O}$ was received. Conversion to $\mathrm{CO}_{2}$ equivalent (coefficient 300) gives $477 \mathrm{~N}_{2} \mathrm{O}$ kt CO2 e. The largest emission of $\mathrm{N}_{2} \mathrm{O}$ is obtained from dairy cow manure.

A carbon dioxide emission $1.989 \mathrm{kgCO}_{2} \mathrm{~m}^{-3}$ was used to calculate $\mathrm{CO}_{2}$ emissions during the barn period. The calculation results are shown in Table 4.

Carbon dioxide $\left(\mathrm{CO}_{2}\right)$ emissions from manure systems (2017)

Table 4

\begin{tabular}{|c|c|c|c|}
\hline $\begin{array}{c}\text { Livestock } \\
\text { category }\end{array}$ & $\begin{array}{c}\text { Quantity of } \\
\text { manure, thousand, } \mathbf{t}\end{array}$ & $\begin{array}{c}\text { Quantity of litter } \\
\text { manure, thousand, } \mathbf{~ m}^{\mathbf{3}}\end{array}$ & $\begin{array}{c}\text { Emission of carbon } \\
\text { dioxide, } \mathbf{k t C O}_{\mathbf{2}}\end{array}$ \\
\hline Cattle & 286.6 & 229.3 & 0.46 \\
\hline Dairy cows & 391.3 & 313.0 & 0.62 \\
\hline Swine & 230.3 & 184.2 & 0.37 \\
\hline Poultry & 333.4 & 266.7 & 0.52 \\
\hline Others & 56.8 & 45.4 & 0.09 \\
\hline Total & 1298.4 & 1038.4 & 2.06 \\
\hline
\end{tabular}

By livestock category, the highest $\mathrm{CO}_{2}$ emission is from cow and poultry manure. The total $\mathrm{CO}_{2}$ emission of manure management systems during the barn period was $2.06 \mathrm{ktCO}_{2}$, from soils there was $74.8 \mathrm{ktCO}_{2}$, methane $\left(\mathrm{CH}_{4}\right) 303.4 \mathrm{kt} \mathrm{CO}_{2} \mathrm{e}$ and dinitrogen monoxide $\left(\mathrm{N}_{2} \mathrm{O}\right)$ emission was $441.8 \mathrm{kt} \mathrm{CO}_{2} \mathrm{e}$.

The calculations of GHG emissions in soils and fields estimated that 1038.7 thousand tons of litter manure were released per year; during the grazing period, about 846.6 thousand of livestock was grazed, and about 200 thousand hectares of soils and fields were fertilized by litter manure. The calculation results are shown in Table 5. 
Calculated GHG emissions in soils and fields (2018)

\begin{tabular}{|c|c|c|c|c|}
\hline $\begin{array}{l}\text { Livestock } \\
\text { category }\end{array}$ & $\begin{array}{c}\text { Quantities of manure } \\
\text { spread in soils, thousand, } t\end{array}$ & $\begin{array}{c}\mathrm{N}_{2} \mathrm{O} \\
\mathrm{kt} \mathrm{CO}\end{array}$ & $\begin{array}{c}\mathrm{CH}_{4} \\
{\mathrm{kt} \mathrm{CO}_{2} \mathrm{e}}^{-}\end{array}$ & $\begin{array}{c}\mathrm{CO}_{2} \\
\mathrm{kt} \mathrm{CO}\end{array}$ \\
\hline Cattle & 252.1 & 470.2 & 48.9 & 28.6 \\
\hline Cows & 290,2 & 548.8 & 57.1 & 35.4 \\
\hline Swine & 150.7 & 293.9 & 30.6 & 14.9 \\
\hline Poultry & 290.8 & 548.2 & 53.1 & 33.2 \\
\hline Others & 54.9 & 97.9 & 14.3 & 6.9 \\
\hline Total & 1038.7 & 1959.0 & 204.0 & 119.0 \\
\hline
\end{tabular}

For calculating direct $\mathrm{N}_{2} \mathrm{O}$ emissions, nitrogen excretion from manure is assumed to be $0.02 \mathrm{~kg}$ $\mathrm{N}_{2} \mathrm{O}-\mathrm{N} \cdot(\mathrm{kg} \mathrm{N})^{-1}$ and soil fertilized manure emissions are $8 \mathrm{~kg} \mathrm{~N}_{2} \mathrm{O}-\mathrm{N} \cdot(\mathrm{kg} \mathrm{N})^{-1}[6]$.

Having performed calculations, it was shown that direct $\mathrm{N}_{2} \mathrm{O}$ emission from spreading manure was $2.078 \mathrm{ktN}_{2} \mathrm{O}(624 \mathrm{kt} \mathrm{CO} 2 \mathrm{e})$, from grazing livestock $2.85 \mathrm{ktN}_{2} \mathrm{O}(855 \mathrm{kt} \mathrm{CO} 2 \mathrm{e})$ and from cultivated soils $1.6 \mathrm{ktN}_{2} \mathrm{O}\left(480 \mathrm{kt} \mathrm{CO} 2 \mathrm{e}\right.$ ). The total $\mathrm{N}_{2} \mathrm{O}$ emissions in the $\mathrm{CO}_{2}$ equivalent of the pasture period were $1959 \mathrm{kt} \mathrm{CO} 2 \mathrm{e}$.

The calculated $\mathrm{CH}_{4}$ emission during the grazing period was $8.16 \mathrm{ktCH}_{4}(204 \mathrm{kt} \mathrm{CO} 2 \mathrm{e})$. Based on manure emissions from fields and livestock, $\mathrm{CO}_{2}$ emissions were $119.5 \mathrm{kt} \mathrm{CO}_{2}$. Then, the total emissions of the main climate changing gases over a 6 month period are about $2282 \mathrm{kt} \mathrm{CO} 2 \mathrm{e}$.

Enterprise "Agrolinija" applies two manure management systems. The first one is dedicated to the production of compost and granular organic fertilizers and includes 4 stages of manure management: manure storage in a barn, manure composting, compost maturation and production of milled compost and granules. The second manure management system involves accumulation of the manure in the manure shed and spreading of manure in the fields and soils. According to the requirements of the Best Practice, more than 40 different ways of handling manure are identified [10]. The most widely used technologies can be divided into autonomous (typical for small and medium-sized farms) and less common primary and secondary manure treatment technologies, which should result in the production of already purified organic product in the form of fertilizers.

The experimental investigations were carried out to measure $\mathrm{CO}_{2}$ emissions from the technological operations of fresh cattle manure; it is composting; maturation of compost and production of milled compost and granules (Fig. 2).

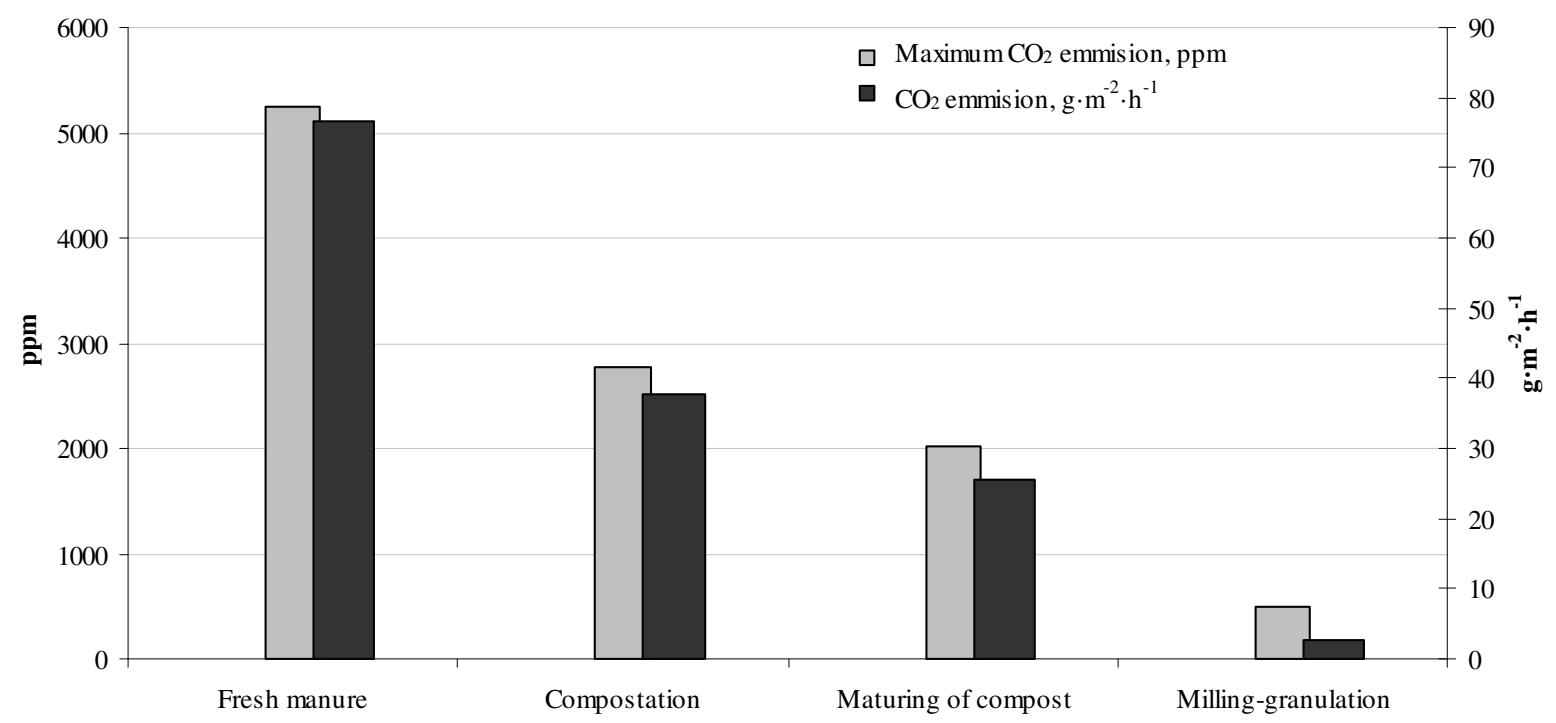

Fig.2. Measured carbon dioxide $\left(\mathrm{CO}_{2}\right)$ emissions from technological operations of milled compost and granule production 
Measurements of $\mathrm{CO}_{2}$ emissions showed that the spread of compostable livestock manure samples over $0.5 \mathrm{~m}^{2}$ area and at the temperature $20^{\circ} \mathrm{C}$ the maximum $\mathrm{CO}_{2}$ changed from $5240 \mathrm{ppm}$ to $578 \mathrm{ppm}$, and $\mathrm{CO}_{2}$ emission from composted manure varied from 76.7 to $2.75 \mathrm{~g} \cdot \mathrm{m}^{-2} \cdot \mathrm{h}^{-1}$.

\section{Conclusions}

1. From 2011 to 2016, the number of holdings with up to 50 animals decreased by $41 \%$, however, the number of farms keeping 50 and more animal increased by $17 \%$.

2. Having performed calculations of emissions, it appeared that the total GHG emissions of manure management systems in $\mathrm{CO}_{2}$ equivalents are about $862.06 \mathrm{kt} \mathrm{CO} 2 \mathrm{e}$ in 2017 . The largest emissions of dinitrogen monoxide $\left(\mathrm{N}_{2} \mathrm{O}\right)$ and carbon dioxide $\left(\mathrm{CO}_{2}\right)$ are from dairy cow manure, and the highest methane $\left(\mathrm{CH}_{4}\right)$ emissions were from poultry manure in Lithuania.

3. During the grazing period, total spread manure emissions in fields and soils amount was about $2282 \mathrm{kt} \mathrm{CO} 2$ e in 2017. About $86 \%$ of these emissions generate dinitrogen monoxide $\left(\mathrm{N}_{2} \mathrm{O}\right)$, and only about $8 \%$ of methane $\left(\mathrm{CH}_{4}\right)$ and $6 \%$ of carbon dioxide $\left(\mathrm{CO}_{2}\right)$ emissions in Lithuania.

4. Experimental measurements in the study object have shown that the maximum $\mathrm{CO}_{2}$ emission of the final product, milled cattle compost and its granules, is 9 times lower, and $\mathrm{CO}_{2}$ emission according to gas mass of manure area unit is up to 28 times lower than of fresh manure.

\section{References}

[1] Konstantinavičiūtė I. Nacionalinių išmetamų ị atmosferą šiltnamio efektą sukeliančių dujų kiekio prognozių rengimo metodinių gairių parengimas. Galutinè ataskaita. 2016 (Development of methodological guidelines for the preparation of national projections of greenhouse gas emissions. Final report. 2016) Kaunas: Lietuvos energetikos institutas. 2016. 251 p. (In Lithuanian). [online] [30.12.2019]. Available at: https://am.lrv.lt/uploads/am/documents/files/KLIMATO \%20KAITA/Studijos\%2C\%20metodin $\%$ C4\%97\%20med \%C5\%BEiaga/Galutine_ataskaita_20170109.pdf

[2] Lithuania's Greenhouse Gas Inventory Report 2019. [online][24.02.2020]. Available at: https://am.lrv.lt/uploads/am/documents/files/KLIMATO\%20KAITA/Studijos\%2C\%20metodin\% C4\%97\%20med\%C5\%BEiaga/NIR_2019_01_15_FINAL.pdf

[3] Mohammed S., Alsafadi K., Takács I., Harsányi E. Contemporary changes of greenhouse gases emission from the agricultural sector in the EU-27. Geology, Ecology, and Landscapes, 2019. pp. 1-6.

[4] Lesschen J. P., Van den Berg M., Westhoek H. J., Witzke H. P., Oenema O. Greenhouse gas emission profiles of European livestock sectors. Animal Feed Science and Technology, 166, 2011, pp. 16-28.

[5] Nacionalinė 2014-2020 metu gyvulininkystès sektoriaus plètros programa (National Program for the Development of the Livestock Sector 2014-2020). State News, 2013-12-27, No. 134-6831. (In Lithuanian).

[6] IPCC 2006 Guidelines for National Greenhouse Gas Inventories - Volume 4: Agriculture, Forestry and Other Land Use-Chapter 10: Emissions from livestock and manure management. [online] [25.02.2020]. Available at: https://www.ipccnggip.iges.or.jp/public/2006gl/pdf/4_Volume4/V4_10_Ch10_Livestock.pdf

[7] Mešlo ir srutų tvarkymo aplinkosaugos reikalavimų aprašas (Description of environmental requirements for manure and slurry management). State News, 2005-07-30, No. 92-3434. (In Lithuanian).

[8] Matulaitis R., Juškienė V., Juška R. Gaseous emissions from manure as affected by microbialbased additive and temperature. Veterinarija ir Zootechnika, vol. 64.86, 2013, pp. 55-64.

[9] Agriculture and environment. Statistic Lithuania. 2018. [online] [27.02.2019]. Available at: https://osp.stat.gov.lt/services-portlet/pub-edition-file?id $=31980$

[10] Best available technologies for manure treatment. Published by Baltic Sea 2020, Stockholm, 2010. 102 p. [online] [26.011.2019]. Available at:

http://www.balticsea2020.org/english/images/Bilagor/ippp\%2020100201\%20best_practice_manu re_handling_final.pdf 